\title{
Universal adhesive systems in class II amalgam restorations
}

Armiliana Soares Nascimento ${ }^{a}$, Eliane Alves de Lima ${ }^{a}$, Yasmine de Carvalho Souza ${ }^{\mathrm{a}}$, Joseane Delfino Canto ${ }^{\mathrm{a}}$, Márcia de Almeida Durão ${ }^{a}$, Rodivan Braz ${ }^{a}$

\section{ABSTRACT}

Objective: To assess the effectiveness of adhesive system in reducing microleakage in class ॥ amalgam restorations.

Methods: The teeth were divided randomly into 3 equal groups: Group I was the control experiment (Copal Vanish); Group II: single Bond Universal 3M-ESPE (with and without acid - 37\%); and Group III: All Bond Universal - BISCO (with and without acid - 37\%), after the amalgam was condensed. The root apices were then sealed with acrylic resin and stored for 24 hours in 100\% humidity. After storage, the specimens were subjected to 500 cycles of thermocycling $\left(5^{\circ} \mathrm{C}\right.$ and $\left.55^{\circ} \mathrm{C}\right)$. The teeth were isolated with cosmetic nail polish and were immersed in 0.5 basic fuchsin dye for 24 hours. The teeth then were sectioned with a diamond disc and observed under a stereomicroscope. Microleakage was assessed using a 0-3 scale of dye penetration. The data was analyzed using the Kruskal-Wallis test $(p<0.05)$.

Results: The microleakage scores revealed less leakage in the experimental groups than in the control group. The microleakage for the adhesives without acid conditioning was reduced, although no statistical significance was recorded $(p<0.05)$.

Conclusion: The immediate adhesive material acted effectively as a barrier for microleakage when it was applied without acid.

Key words: Adhesives; Universal adhesive; Amalgams; Microleakage; Class II

\section{Sistema adesivo universal em restaurações de amálgama classe II \\ RESUMO}

Objetivo: Avaliar a eficácia do sistema adesivo na redução da microinfiltração em restaurações de amálgama classe II.

Metodologia: Os dentes foram divididos aleatoriamente em três grupos iguais: Grupo I foi o controle (Copal Vanish); Grupo II: Single Bond Universal 3M ESPE - (com e sem ácido - 37\%); e Grupo III: All bond Universal - BISCO (com e sem ácido - 37\%) com posterior condessação do amálgama. Os ápices foram então seladas com resina acrílica e armazenado durante 24 horas em 100\% de humidade. Após a armazenagem, as amostras foram submetidas a 500 ciclos de termociclagem $\left(5^{\circ} \mathrm{C}\right.$ e $\left.55^{\circ} \mathrm{C}\right)$. Os dentes foram isolados com esmalte para unha e foram imersos em 0,5 de fucsina básica por 24 horas. Em seguida os dentes foram seccionados com disco de diamante e observados sob microscópio estereoscópico. A microinfiltração foi avaliada usando uma escala de penetração do corante de 0-3. Os dados foram analisados utilizando o teste de Kruskal-Wallis $(p<0,05)$

Resultados: Os escores revelaram menor infiltração nos grupos experimentais do que no grupo de controle. A infiltração para os adesivos sem condicionamento ácido foi reduzida, embora sem significância estatística $(p<0,05)$.

Conclusão: O material adesivo imediato atuou efetivamente como uma barreira para microinfiltração, quando foi aplicada sem condicionamento ácido.

Palavras-chave: Adesivos; Adesivo universal; Amálgama; Micro-infiltração; Classe II
${ }^{a}$ Departmant of Dentistry, University of Pernambuco, Recife, PE, Brazil

西 


\section{INTRODUCTION}

The penetration of fluids and bacteria in the restorative interface remains one of the principal problems of odontology and is directly associated with the longevity of restorations. Marginal micro-infiltration leads to problems such as the early loss of the restoration due to recurring caries, postoperative sensitivity or pulpal damage $[1,2,3]$.

Several approaches have been proposed for the use of amalgam restorations in an attempt to reduce marginal infiltration. There is a greater emphasis on basic materials, modified glass ionomer cements and adhesive resin [4]. Among cavity sealers, adhesive systems have exhibited a better performance than cavity varnish [5].

The use of adhesive systems is supported by the results of in vivo [6-7] and in vitro studies [4-8], which reported significantly greater reductions in micro-infiltration with adhesive systems than with varnish [9-11]. Adhesives form a bond and/or molecular interaction between the amalgam and the dental structure, unlike varnish which only establishes a mechanical connection [12].

Recently, the advent of universal adhesive systems has promised adhesiveness to metallic structures $[13,14]$. The aim of the present study was to perform an in vitro assessment of the efficiency of two universal adhesive systems in terms of the reduction of marginal micro-infiltration in amalgam class II restorations. Conventional and self-etching adhesive systems were applied.

\section{METHODS}

Fifteen non-carious and defect-free human premolars and molars, recently extracted for therapeutic purposes, were selected. Immediately after extraction, the teeth were cleaned of all debris with a curette and an aqueous slurry of pumice, using a soft polishing brush at a low speed. The teeth were stored in $0.1 \%$ Thymol solution at room temperature. The teeth were randomly divided into three groups (Group I [control], Group II and Group III) of five. Twenty-five class II (slot) cavities were prepared from human premolars and molars on the mesial and distal surfaces of the gingival wall in cementum. All preparations were performed using cylindrical Diamond Rotary cutting instruments (\#3145; KG Sorensen, São Paulo, Brazil) at high-speed and cooled with an air-water spray.

The adhesives were applied in each of the groups: Group I was the control experiment (Copal Vanish); a single Bond Universal 3M-ESPE (with and without acid conditioning - 37\%) was used in Group II and All Bond Universal BISCO (with and without acid conditioning - 37\%) was used in Group III. Table 1 displays the materials used, the manufacturers, the composition and the modes of application.

Subsequently, the adhesives were light-polymerized with a visible light-polymerizing unit (Optilux 400; Demetron, Danbury, Conn) at a distance of $1 \mathrm{~mm}$. The intensity of the light was monitored periodically with the same light unit, remaining consistently in the range of $400-450 \mathrm{~mW} / \mathrm{cm}^{2}$. The amalgam was condensed using small condensers and applied, after the application of the adhesives and varnish, by one (1) operator. The condensation was probably superior to that usually carried out clinically due to the perfect accessibility of the teeth in vitro. The preparations were slightly overfilled and the restoration was burnished with a large burnisher. A carver (Hollenback; American Eagle Instruments Inc) was used to remove the excess amalgam and restore the contour of the tooth.

The root apices were then sealed with acrylic resin and the teeth were stored for 24 hours in $100 \%$ humidity at $37^{\circ} \mathrm{C}$.

The specimens were stored and polished. Samples from each group were subjected to 500 cycles of thermocycling $\left(5^{\circ} \mathrm{C}\right.$ and $\left.55^{\circ} \mathrm{C}\right)$ using a dwell time of one minute. The teeth were isolated with a cosmetic nail polish $(1 \mathrm{~mm}$ around the restoration) and were then immersed in 0.5 basic fuchsin dye for 24 hours at room temperature. Subsequently, they were rinsed with water and lightly brushed with pumice slurry to remove the superficial dye. Each tooth was sectioned longitudinally in the mesio-distal direction along each restoration using a slow-speed water-cooled diamond saw.

Table 1. Manufacturers, composition, mode of application, and batch numbers of materials used.

\begin{tabular}{|c|c|c|c|c|}
\hline Material & Manufacturer & Composition & Mode of application & Bath no. \\
\hline Varnal & $\begin{array}{l}\text { Biodinâmica, } \\
\text { Europa S.L }\end{array}$ & $\begin{array}{l}\text { Resin staybilite (Ester 10) and } \\
\text { Dimetylcetone }\end{array}$ & $\begin{array}{l}\text { Apply first layer and dry lightly (30s) } \\
\text { Apply second layer } \\
\text { Dry lightly (30s) }\end{array}$ & $673-13$ \\
\hline Single Bond Universal & 3M ESPE Germany & $\begin{array}{l}\text { MDP Phosphate Monomer, } \\
\text { Dimethacrylate resins, HEMA, } \\
\text { Vitrebond }{ }^{\text {IM }} \text { Copolymer, Filler, Ethanol, } \\
\text { Water, Initiators, Silane }\end{array}$ & $\begin{array}{l}\text { 1. Apply first layer, brush for } 20 \text { s. } \\
\text { 2. Dry lightly ( } 30 \mathrm{~s}) \\
\text { 3. Apply second layer, brush for } 20 \text { s } \\
\text { 4. Dry lightly ( } 30 \mathrm{~s}) \\
\text { 5. Light curing (10s) }\end{array}$ & 41282 \\
\hline All Bond Universal & BISCO USA & $\begin{array}{l}\text { Bis-GMA, 10-MDP, HEMA, ethanol, } \\
\text { initiators, water }\end{array}$ & $\begin{array}{l}\text { Apply first layer, brush for } 20 \mathrm{~s} . \\
\text { Dry lightly (30s) } \\
\text { Apply second layer, brush for 20s. } \\
\text { Dry lightly (30s) } \\
\text { Light curing (10s) }\end{array}$ & B-72020K \\
\hline $\begin{array}{l}\text { Velvalloy spherical } \\
\text { high-copper }\end{array}$ & S.S. White Brazil & $\begin{array}{l}\text { Mercury: alloy } 1: 0.74,57.5 / 42.5 \%) \\
\text { Single composition spherical alloy: } \\
12 \mathrm{wt} \% \mathrm{Cu}, 28 \mathrm{wt} \% \mathrm{Sn} \text {, and 60wt } \mathrm{Ag}\end{array}$ & $\begin{array}{l}\text { Activate capsule } \\
\text { Place capsule in amalgamator } \\
\text { Triturate for } 12 \mathrm{~s} \\
\text { Condense amalgam }\end{array}$ & OOR \\
\hline
\end{tabular}


Examinations of the specimens were carried out in random order. All investigators were unaware of the exact nature of the restorative treatment being assessed. If conflicts in scores occurred, a consensus was obtained between the observers.

The staining along the tooth restoration interface was recorded according to the following criteria: 0 , no dye penetration; 1 , dye penetration along the enamel; 2 , dye penetration along the dentine-enamel junction (DEJ), but not including the axial wall; 3 , dye penetration to and along the axial wall.

Data were analyzed using absolute frequencies and percentages. To verify the hypothesis of significant differences, the Mann-Whitney test for the comparison of two categories or two groups, as well as the Kruskal-Wallis test, were used to compare microleakage in three different groups filled by three different materials $(p<0.05)$.
The margin of error used in the statistical tests was 5\%. The statistical software used for data entry and the retrieval of statistical calculations was the Statistical Package for Social Sciences (SPSS), version 21.

\section{RESULTS}

Table 2 displays the mean values of dye penetration for the cervical margin location in the different groups. Cohen's Kappa test confirmed an excellent agreement between the examiners $(\mathrm{k}=0.91)$. Figure 1 displays the statistical analysis of the different combinations from the experimental design. In general, the interaction between the main factors was not significant $(p<0.05)$ for the cervical margins. The microleakage adhesive without acid conditioning provided a reduction, although not a statistically significant one $(p<0.05)$.

Table 2. Mean value of posts for the presence or absence of acid for each adhesive used

\begin{tabular}{|c|c|c|c|c|c|}
\hline \multirow{2}{*}{ Bonding agent } & \multicolumn{2}{|c|}{ Mean of post } & \multicolumn{2}{|c|}{ Etching } & \multirow{2}{*}{$p$ value } \\
\hline & With & Without & With & Without & \\
\hline - Varnish - Control & & 17,2 & & 3,00 & * \\
\hline - Single Bond Universal & 15,40 & 10,0 & 6,50 & 4,50 & $\mathrm{p}^{(1)}=0,444$ \\
\hline - All Bond 2 Universal & 12,40 & 10,0 & 6,00 & 5,00 & $\mathrm{p}^{(1)}=1,000$ \\
\hline
\end{tabular}

* Not determined due to the presence of only one category.

(1) Using the Mann-Whitney test to compare the presence or absence of acid conditioning.

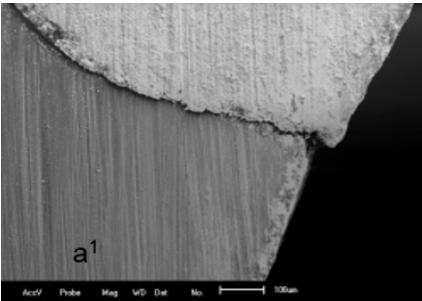

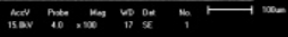

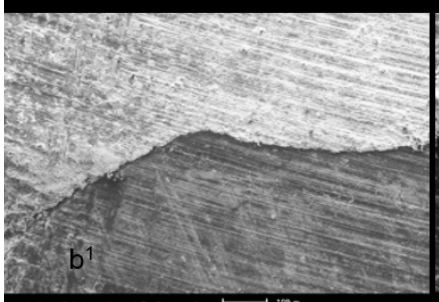

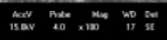

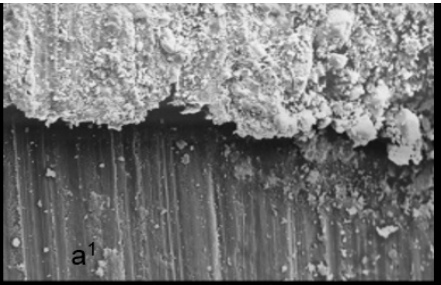

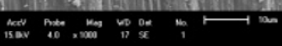

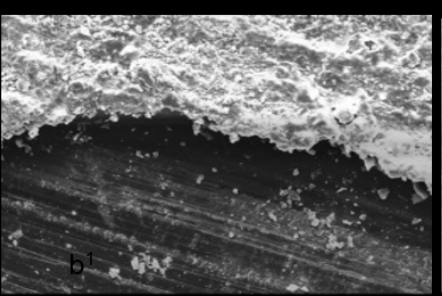

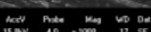
$\prod^{\infty}$

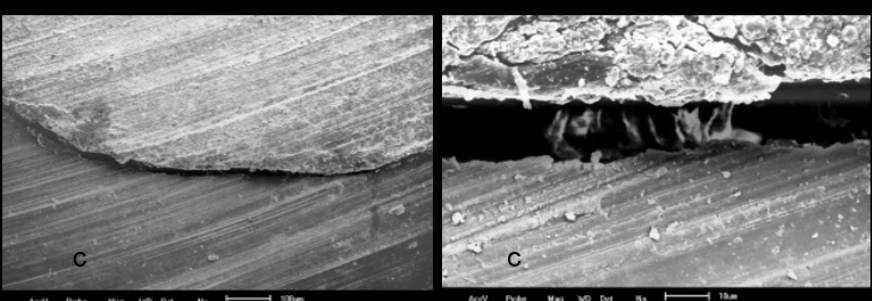

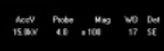

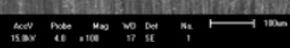

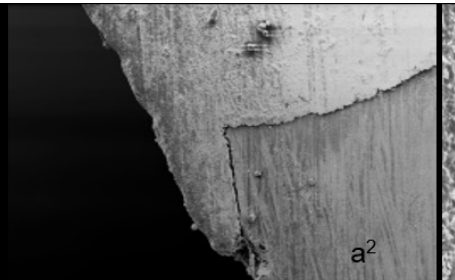
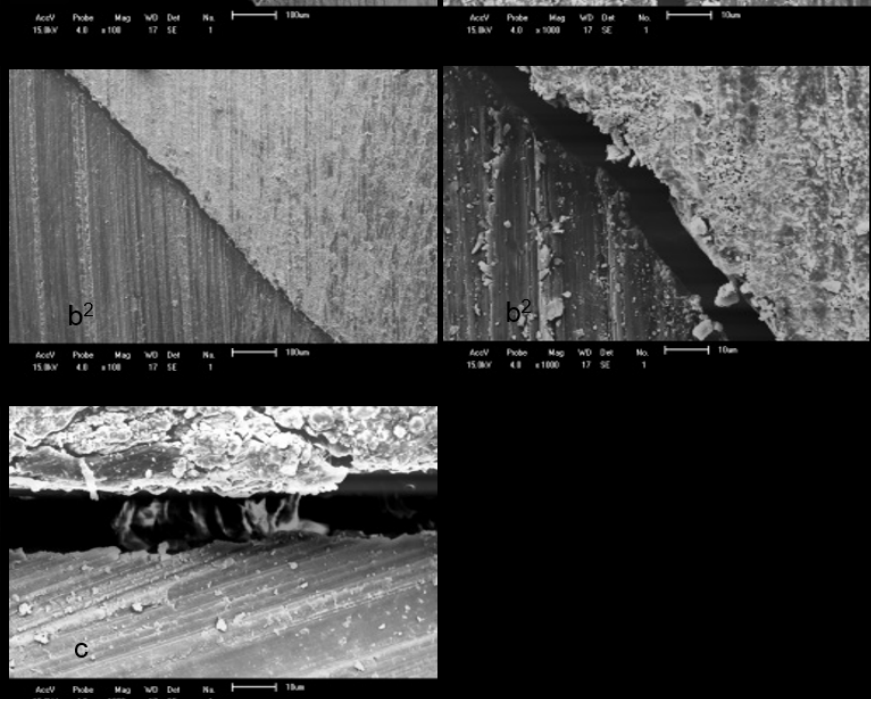

Figure 1. $\left(a^{1}\right)$ Amalgam/single bond universal interfaces with acid/dentin; $\left(a^{2}\right)$ Amalgam/single bond universal interfaces without acid/dentin;

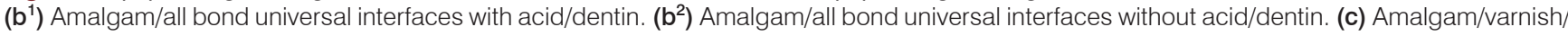
dentin interfaces (SEM at 100X and 1000X). There is gap formation along the interface. 


\section{DISCUSSION}

Marginal infiltration in the bond interface remains one of the principal challenges in odontology. Therefore, studies involving this methodology have become necessary, particularly in in vitro experiments. McCurdy Jr. et al. [15] reported that micro-infiltration is greater in in vitro studies than in in vivo studies, when using pulped teeth. This is probably due to the fluid movement of dentinal tubules, which occurs in the opposite direction to dye penetration. It could also be caused by the oxidation and corrosion suffered by the amalgam, sealing the margins of the restoration more quickly upon contact with oral fluids [16]. Another factor that can hinder, or prevent, dye penetration is the presence of sclerotic dentin [17].

In most in vitro tests, there are variations in the period of storage, which can be 24 hours, a week, two weeks, 3,6 or 12 months $[18,11,19]$. The storage time in the present study was 24 hours. Thus, the short-term assessment probably affected the results.

The scientific literature contains studies reporting a reduction in infiltration based on the use of adhesive systems [11-20] over a short-term assessment period. Thus, shortterm results are material-dependent, given that long-term assessments have shown that the adhesive is not the dominant factor in terms of reducing infiltration around amalgam restorations [11]. Since adhesive systems are susceptible to hydrolytic degradation, this could explain the reduced bond between dentin and restorative material, thereby favoring the penetration of fluids and bacteria [21]. Moraes et al. [22] assessed the influence of storage time by analyzing marginal infiltration related to the sealing of amalgam restorations. The authors reported that restorations sealed with the Single Bond adhesive exhibited significantly lower amounts of infiltration than the other groups $(p<0.001)$. After 15 months of storage, none of the groups tested exhibited an improved sealing capacity, whereas the group sealed with the Single Bond adhesive exhibited significantly higher scores for dye penetration $(p<0.001)$. Moore et al. [23] showed that the positive influence of adhesives, in terms of the prevention of infiltration, only lasted six months and became insignificant after one year of storage.

The aim of the present study was to use marginal microinfiltration tests to assess the sealing capacity of two universal/ multi-mode adhesive systems (Single Bond - 3M/ESPE; All Bond-BISCO), using conventional and self-etching techniques. The results were compared with sealing conducted using cavity varnish. The use of universal adhesive systems in restorations has been justified based on their affinity with metallic components $[13,14]$. The results of the present study suggest that the presence of an adhesive agent significantly reduced marginal micro-infiltration, when compared with the control group, in amalgam restorations. All-Bond Universal incorporates 10-methacryloyloxydecyl dihydrogen phosphate (MDP) which, unlike other monomers, bonds chemically with $\mathrm{Ca}^{++}$ions and forms stable MDP-Ca salts, according to the concept of "adhesion-decalcification". This phenomenon makes the interface more resistant to biodegradation [13].
With regards to the Single Bond Universal adhesive system, studies have shown its capacity for chemical adhesion to teeth, although the results are slightly worse than those found for Clearfil SE Bond. This may be due to interaction between the different chemical components present in the material $[24,25]$.

Analysis of the infiltration of the dye confirmed that none of the three systems applied were capable of eliminating marginal micro-infiltration, although it was lower for restorations associated with dentin adhesives than for those associated with cavity varnish. Oliveira et al. [26] concluded that none of these three restorative systems were capable of eliminating marginal infiltration, similar to the results of the present study. However, marginal infiltration it was lower and statistically significant for restorations associated with dentin adhesives, when compared with cavity varnish. Junior et al. [27] also obtained less marginal infiltration when using the adhesive system All Bond 2/Resinomer than when using a glass ionomer cement (Vitrebond), the latter of which was better than the control group (Copaline Varnish). On the other hand, Guiraldo et al. [4] assessed the marginal adaptation of cavities restored with silver amalgam and adhesive systems and concluded that the worst marginal adaptation was found in the control group (restoration without sealers), with a statistically significant difference when compared with the other groups (G I: adhesive Prime \& Bond 2.1 - Dentsply; G II: acid conditioning, application of the adhesive Single Bond and the resin cement Rely X-3M-ESPE; G III: glass ionomer cement Rely X Luting - 3M-ESPE). The experimental groups did not differ statistically between each other.

When the universal adhesive system was applied in its self-etching mode, the dye penetration scores were reduced by $100 \%$ in relation to the conventional mode, for both of the adhesives studied ( 24 hour storage time). Universal adhesive systems exhibit similar components to single-step self-etching adhesives, in that they possess the functional monomer MDP, thereby enabling the acidic function and posterior chemical adhesion.

Self-etching adhesive systems with a $\mathrm{pH}$ of 2.7 partially demineralize dentin, leaving a considerable quantity of hydroxyapatite crystals around and inside collagen fibers. This residual hydroxyapatite is fundamental to the chemical interaction of functional monomers and effective chemical and micromechanical adhesion [28]. The use of self-etching adhesives favors the demineralization and infiltration of the dentin surface at the same depth, theoretically impeding adhesive failure. However, Carvalho et al. [29] reported cases of nano-infiltration along the interface, suggesting that acidic monomers were gradually buffered by the mineral content of the substrate and partially conditioned the dentin. Consequently, areas or partially demineralized, although not infiltrated, dentin was produced below the hybrid layer. This result is contrary to the concept that there is no discrepancy between the depth of demineralization and the depth of adhesive infiltration.

Other factors such as the method of application, the type of solvent and the $\mathrm{Ph}$ could help to explain the results found herein, particularly in relation to vigorous application. It has 
previously been demonstrated that the vigorous application of self-etching adhesives improves the immediate bond strength and decreases bond degradation over time [30,31]. The adequate control of dentin moisture is fundamental for the posterior diffusion of resinous monomers, particularly the vapor pressure of the solvent, which is directly associated with adhesive quality [31].

The results obtained in the photomicrography (SEN) suggested that less gaps were formed when adhesive systems were used on the restoration. Iregui [32] used photomicrography to demonstrate the occurrence of micromechanical retention between the adhesive and the amalgam, although they also showed that most of the adhesion came from the adhesive/dentin interface. Cavity varnish did not prevent marginal infiltration and provided the worst results overall. This could have been caused by flaws in the layers applied, such as porosities or cracks, or even the dissolution of the material. This is contrary to the findings of Barbosa et al. [33] who found that both conventional and fluoride varnish exhibited low levels of marginal infiltration when used to pre-treat amalgam restorations. Results similar to those of the present study have been previously reported by Pucci et al. [34], Pinto et al. [5], Sanvieiro et al. [35].

Within the limitations of the present study, it can be concluded that the immediate adhesive material acted effectively as a barrier for microleakage when it was applied without acid. This adhesive should be recommended for amalgam restorations.

\section{REFERENCES}

1. De Munck J, Van Landuyt K, Peumans M, et al. A critical review of the durability of adhesion to tooth tissue: methods and results. J Dent Res 2005a, 84(2): 118-32. https://doi.org/10.1177/154405910508400204

2. Mali $P$, Deshpande S, Singh A. Microleakage of restorative materials: an in vitro study. J Indian Soc Pedod Prev Dent. 2006; 24: 15-8. https://doi. org/10.4103/0970-4388.22828

3. Hashimoto $M$, Ohno $H$, Sano $H$, Kaga M, Oguchi $H$. in vitro degradation of resin-dentin bonds analyzed by microtensile bond test, scanning and transmission eléctron microscopy. Biomaterials 2003a,24(21):3795-803. https://doi.org/10.1016/S0142-9612(03)00262-X

4. Guiraldo RD, Consani S, Santos P H, Sinhoreti M A C, Correr Sobrinho L. Adaptação marginal em restaurações de amálgama de prata associada às técnicas adesivas. Rev Odont Ara 2007,.28 (1):39-43

5. Pinto MB. Microleakage in silver amalgam restorations under the influence of condensation forms and use of intermediate materials in marginal interface 2001. 125f. (Doctorate in Dentistry) - Postgraduate Course in Dentistry, Dental Materials, Campinas, Piracicaba.

6. Setcos JC, Staninec M, Wilson NH. A two-year randomized, controlled clinical evaluation of bonded amalgam restorations. J Adhes Dent 1999; 1:323-31.

7. Mahler DB, Engle JH. Clinical evaluation of amalgam bonding in Class I and || restorations. J Am Dent Assoc 2000:131:43-9. https://doi. org/10.14219/jada.archive.2000.0018

8. Ben-Amar A, Nordenberg D, Liberman R, Fischer J, Gorfil C. The control of marginal microleakage in amalgam restorations using a dentin adhesive: a pilot study. Dent Mater 1987;3:94-6. https://doi.org/10.1016/S01095641(87)80013-1

9. Staninec M, Holt M. Bonding of amalgam to tooth structure: tensile adhesion and microleakage tests. J Prosthet Dent 1988;59:397-402. https://doi.org/10.1016/0022-3913(88)90030-3

10. Turner EW, St. Germain HA, Meiers JC. Microleakage of dentin-amalgam bonding agents. Am J Dent 1995;8:191-6.

11. Ziskind D, Venezia E,Kreisman I, Mass E. Amalgam type, adhesive system, and storage period as influencing factors on microleakage of amalgam restorations. J Prost Dent 2003, 90(3):2 55-60. https://doi.org/10.1016/ S0022-3913(03)00421-9
12. Amin VM. Comparative study of the sealingefficacy of various bondingsystems to Class $\mathrm{V}$ dental amalgam restorations. Inter J Adhes Adhes 2006, 26: 145-150. https://doi.org/10.1016/j.ijadhadh.2005.03.002

13. Chen L, Suh B. New one-bottle self-etch adhesive is compatible with selfcure materials. Presented at: American Association for Dental Research Annual Meeting; March 24, 2012; Tampa, Florida.

14. Suh BI. Universal Adhesives: The Evolution of Adhesive Solutions Continues. COMPENDIUM 2014, 35(4):278.

15. McCURDY Jr. C, Swartz ML, Phillips RW, Rhodes BF. A comparison of in vivo and in vitro microleakage of dental restorations. J Am Dent Assoc 1974, 88: 592-602. https://doi.org/10.14219/jada.archive.1974.0107

16. Ben-Amar A, Cardash HS, Judes $H$. The sealing of the tooth/amalgam interface by corrosion products. J Oral Rehabil 1995;22:101-4

17. Brannstrom, M. Dentin and pulp in restorative dentistry. Wolfe Medical Publication Ltd, Castelnuovo, Italia; 1982:70

18. Li H, Burrow MF \& Tyas MJ. Nanoleakage patterns of four dentin bonding systems. Dent Mat 2000, 16(1) 48-56. https://doi.org/10.1016/S01095641(99)00085-8

19. Reis A, Pellizzaro A, Dal-Bianco K, Gones OM, Patzlaff R, Loguercio AD. Impact of adhesive application to wet and dry dentin on long-term resin-dentin bond strengths. Oper Dent 2007; 32(4):380-7. https://doi. org/10.2341/06-107

20. Cenci MS, Piva E, Potrich F, Formolo E, Demarco FF, Powers JM Microleakage in bonded amalgam restorations using different adhesive materials. Braz Dent J 2004;15:13-8. https://doi.org/10.1590/S010364402004000100003

21. Hashimoto M, Ohno $H$, Kaga M, Endo $K$, Sano $H$, Oguchi $H$. In vivo degradation of resin-dentin bonds in humans over 1 to 3 years. J Dent Res 2000;79:1385-91. https://doi.org/10.1177/00220345000790060601

22. Moraes RR, Lima FG, Bueno M, Demarco FF. Storage time influence on the sealing of amalgam restorations using different liners.. Rev Odontol UNESP 2005, 34(3):135-40.

23. Moore DS, Johnson WW, Kaplan I. A comparison of amalgam microleakage with a 4-META liner and copal varnish. Int J Prosthodont 1995, 8: 461-6.

24. Perdigão J, Sezinando A, Monteiro PC. Laboratory bonding ability of a multi-purpose dentin adhesive. Am J Dent, in press, 2012b.

25. Yoshida Y, Yoshihara K, Nagaoka N, Hayakawa S, Torii Y, Ogawa T, Osaka A, Meerbeek BV. Self-assembled nano-layering at the adhesive interface. $J$ Dent Res 2012; 91(4):376-81. https://doi.org/10.1177/0022034512437375

26. Oliveira FS; Silva SMB; Bijella MFTB, Lima JEO. In vitro evaluation of the marginal microleakage of class II amalgam restoration associated with dentin adhesive. Rev Odontol UNESP 1999, 13(3): 263-8. https://doi. org/10.1590/s0103-06631999000300010

27. Junior Pereira ES, Bijella MFTB, Silva SMB, Vono BG. In vitro evaluation of marginal microleakage of glass II bonded amalgam restorations using a dentin adhesive and a glass ionomer cement. Rev Odontol UNESP 1999, 13(2): 103-9. https://doi.org/10.1590/s0103-06631999000200002

28. Manhart J, Chen H, Hamm G, Hickel R. Buonocore memorial lecture: Review of the clinical survival of direct and indirect restorations in posterior teeth of the permanent dentition. Oper Dent 2004; 29: 481-508.

29. Carvalho RM, Chersoni S, Frankenberger R, Pashley DH, Prati C, Tay FR. A challenge to the conventional wisdom that simultaneous etching and resin infiltration always occurs in self-etch adhesives. Biomaterials 2005:26(9):1035-42. https://doi.org/10.1016/j.biomaterials.2004.04.003

30. do Amaral RC, Stanislawczuk R, Zander-Grande C, Gagler D, Reis A, Loguercio AD. Bond strength and quality of the hybrid layer of onestep self-etch adhesives applied with agitation on dentin. Oper Dent 2010;35(2):211-9. https://doi.org/10.2341/09-198-L

31. Loguercio AD, Stanislawczuk R, Mena-Serrano A, Reis A. Effect of 3-year water storage on the performance of one-step self-etch adhesives applied actively on dentine. J Dent 2011a;39(8):578-87. https://doi.org/10.1016/j. jdent.2011.06.005

32. Reis AF, Oliveira MT, Giannini M, De Goes MF, Rueggeberg FA. The effect of organic solvents on one-bottle adhesives' bond strength to enamel and dentin. Oper Dent. 2003;28(6):700-6.

33. Barbosa JB, Giro EMA, Santos Pinto LAM. Marginal leakage of amalgam restorations: effect of pretreatment of the cavity walls with conventional varnish and fluoride. Rev Odontol UNESP 1997, 26(2): 433-44

34. Pucci CR, Giachetti NJ, Araújo MAX. In vitro microleakage of amalgam. Rev Odontol UNESP 1998, 27(2):459-72

35. Sansvieiro A, Neto ALM, Matumoto MSS, Blas R. Microleakage in restorations of silver amalgam, lined with simple and modified varnish - Study in vitro. Conscientia e saúde. Rev Cient UNINOVE 2003, 2(002): 43-9. 